\title{
最近のカラー写真用有機素材の合成化学
}

\author{
木 村 士 朗*·吉 田 真* \\ Synthetic Chemistry of the Recent Organic Material for \\ Colour Photography.
}

Shirō KIMURA* and Makoto YoshidA*

カラー感光材料が，実用佂值のある商品として世に出 てから，すでに約 30 年になるが； ようやく大衆の生活 の中に深く根を降ろしてきたようである。1861 年に Maxwell が最初のカラー写真を加色法で作り，1861 年 に Hauron は減色法を案出した。減色法は色再現の正 確さの点では加色法に劣るが, 現在, 実用されているカ ラー写真のほとんどは, この減色法である。加色法では 画像そのものに色がなく, 減色法では画像そのものに色 があることが，大きな違いである。このために，減色法 には化学的過程の利用される割合が加色法よりも大き く，それだけ有機化学的にも興味深い分野である。

\section{I. 色像を作る方法}

滅色法で色像を作るには，つぎのような種々の方法が ある。

1. 顔料を含むコロイド層を，作用した光量に比例し て硬化し，末感光部分を洗い去ってリリーフ像を作る方 法 (カーボン印画法, ゴム印画法)。

2. コロイド層を, 作用した光量に比例して硬化し, リリーフ像を作り，その上に顔料をのせたり，染料で染 めたりする方法 (オイル印画法, ブロモイル印画法)。

3. コロイド層を, 作用した光量に比例して硬化し, 末感光部分を洗い去ってリリーフ像を作り，それを染料 で染めてから他の層に転染する方法（転染法印画, テク ニカラー)。

4. 八ロゲン化銀乳剤中に色素を入れておき，画像を 焼付けてできる銀量に比例して, 色素を漂白する方法 (ガスパーカラー, シルクローム)。

* 富士写真フィルム株式会社足柄研究所（神奈川県足 柄上郡南足柄町)

* Ashigara Research Laboratory, Fuji Photo Film Co., Ltd. (Minami Ashigara-machi, Ashigarakami-gun, Kanagawa-ken, Japan)
5. 八ロゲン化銀乳剤に画像を焼付け，現像するとき 生成する銀量に比例して, 色素を生成させる方法（発色 現像法)。

6. 染料現像薬を含む層とハロゲン化銀乳剂層とを隣 接させ，現像するとき生成する銀量に比例して，色素を 拡散させる方法 (ポーラーカラー)

7. 光導電性金属板に画像を焼付け, 染料のオニウム. イオンを含む液中で電気分解により，作用した光量に比 例して，金属板上に染料を析出させる方法 $(3 \mathrm{M} \text { 法 })^{2)}$ 。

8. 光導電性金属板に画像を焼付け, 染料で着色した トナーを，作用した光量に比例して，金属板上に固着さ せるか，または，これを他の層に転染する方法（カラー 電子写真法 $)^{3)}$ 等がある。

この中で, 発色現像法は, 他の方法に比べて印刷類似 の物理的な操作過程がなく, 主として化学的な過程でカ ラー写真が得られる利点がある。また, 最初から, 顔料 ・染料等の着色化合物を使用せず, 現像過程で色素を生 成する点から, 有機反応論的にも扔もしろい研究分野で ある。

よって, 発色現像法カラー写真に使用する有機素材に 焦点をしぼって，最近の約 10 年間における発展の中か ら，代表的なものをあげて，大方諸賢の御参考に供した い。

\section{II. 発色現像の機構}

発色現像法では，感光した八ロゲン化銀が酸化剂とな って, ジアルキルアミノアニリン系の発色現像薬を酸化 し, 生じた酸化生成物が, 発色剂（coupler または colour-former と呼ぶ）とカップリングして色素となる。 したがって, 発色剂が酸化生成物と容易に結合反応を起 すためにも，発色剂の種類は自ら制限される。使用され ている化合物は，主として，分子中に活性メチレン基 か, フェノール性水酸基を持っている物が多いので, 生 
成する色素も，アゾメチン系，およびキノンイミン系の 染料である。

色素生成の反応をつぎに例示する。この反応機構につ いても，種々の研究がなされているが，省略する。
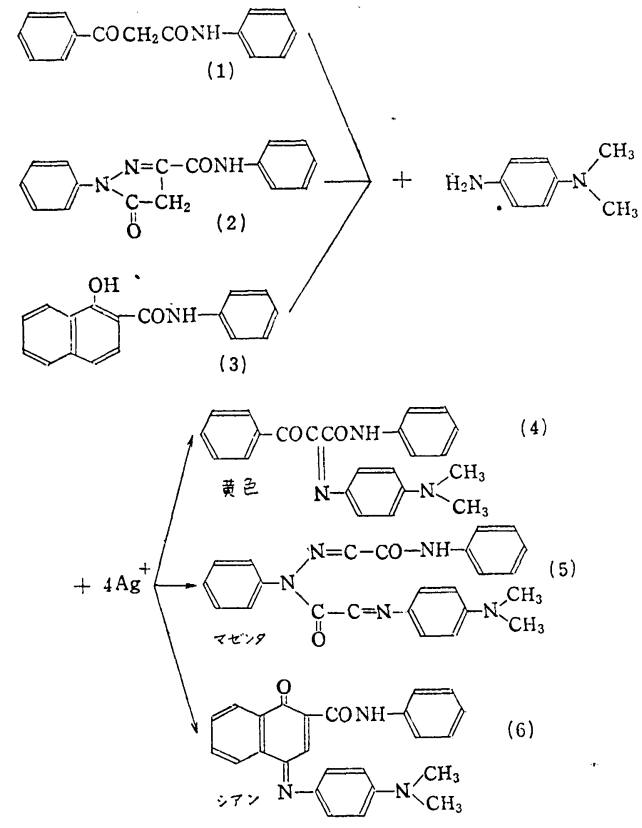

III. カップラー

1. 黄色を与えるカップラー 黄色は可視域の $450 \mathrm{~m} \mu$ 付近に吸収極大をもち， $500 \mathrm{~m} \mu$ 以上を完全に透過する ものであることが望ましい。使用されているものの多く は，太゙ンゾイルアセトアニリド誘導体である。X, Y,R, $\mathrm{R}^{\prime}$ の置換基の変化による, 発色反応速度, 生成色素の吸
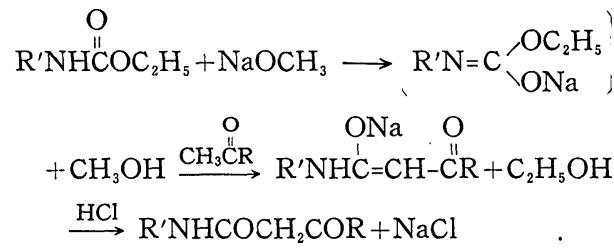

ii. ピバロイルアセトアニリト誘導体 これは, Eastman Kodak 社 (略 E.K $)^{5)}$ が開発したカップラーであ. って, 最近の黄色カップラーの研究の中では, 特記すべ きものであろう。

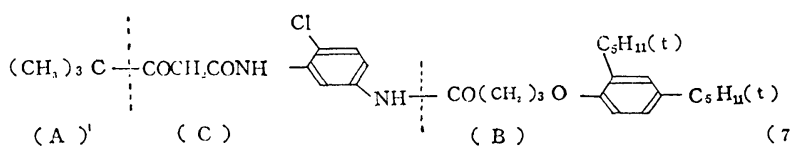

$$
\underset{\mathrm{CH}_{3} \mathrm{CHI}_{2}-\mathrm{CH}-(\mathrm{C})-\text { (B) }}{\mathrm{CH}_{3}} \text { (8) } \quad\left(\mathrm{CH}_{3}\right)_{3} \mathrm{CCH}_{2}-(\mathrm{C})-(\mathrm{B}) \quad \text { (9) }
$$

このピバロイルアセトアニリド系のカップラー(7) は 前記のベンゾイルアセトアニリド系に比べて，発色力が 弱い。しかし，ジーn-ブチルフタレート等のカップラー 溶剂に対する溶解度がよく，特に吸収曲線の長波長部の 切れが鋭く，鮮明な黄色を与える。また，今までのベン ゾイルアセトアニリド系では得られなかった, 高い耐光 堅口ウ度を示し, 同類のカップラー (8) および (9) に比 べても，退色率は 1/4 1/6 である。

最近の特許や報文 ${ }^{6)}$ の中に, $t$-ブチル基をもつ染料 は，耐光堅口ウ度がよく，有機溶㓮にとけ易くなると報 告されているが，このピバロイルアセトアニリド系のか ップラーにも，その特徴が現われている。

原料のピバロイル酶酸エステルの合成には，ピナコリ ンを使用〉してもよい。

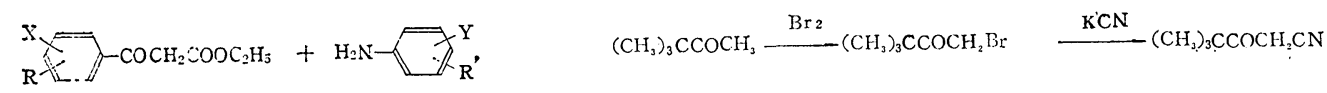

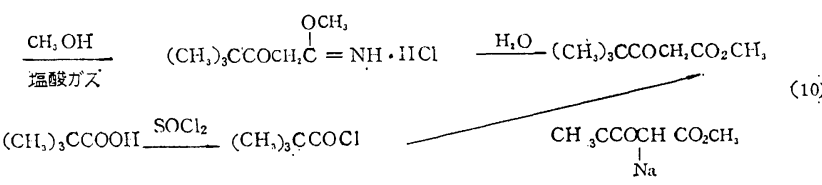

収極大の位置発色濃度，吸収曲線の長波長部 の切れなどが研究の焦点となっている。

i. 新しい合成法 一般にはベンゾイル酢酸エステル 類とアニリン誘導体との縮 合で合成するが，General Aniline 社 (4)はつぎの方法を発表した。強塩基性の縮合 戍のもとで，メチルアリールケトンとアリールインシア ナートあるいは，それらのウレタン誘導体とを反応させ る方法で， $\mathrm{R}$ と $\mathrm{R}^{\prime}$ は芳香族でも複素環化合物でもよい。 その反応機構を次のように推定している。

iii. その他 変った型のものとして代表的なカップ

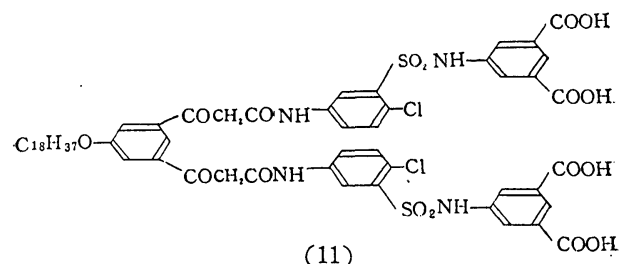


ラーを次にあげる。使用されているカップラーは；分子 中にカップリング官能基を 1 個有するのみであるが，色 素生成率を高め, フィルムの発色濃度を高めるために, 分子中に 2 個のカップリング官能基を導入したもの ${ }^{8)}$ が ある。

また，アニリド基にかわるものとして，複素環を置換 したものがあり，アニリド基を有するものにくらべて， 深色的になる ${ }^{9)}$ 。

$$
\mathrm{C}_{16} \mathrm{II} \mathrm{I}_{33} \mathrm{O}-\mathrm{COCH}_{2} \mathrm{CONH}-\mathrm{C}_{\mathrm{N}}^{\mathrm{S}-\mathrm{CH}}-\mathrm{C}-\mathrm{COOC}_{2} \mathrm{II}_{5}
$$

他のアシルアセトアニリド型よりも活性が大きく，生 成した色素が不溶性になるものとして，アニリド核にフ エニルキナゾロンを置換したものがある10)。
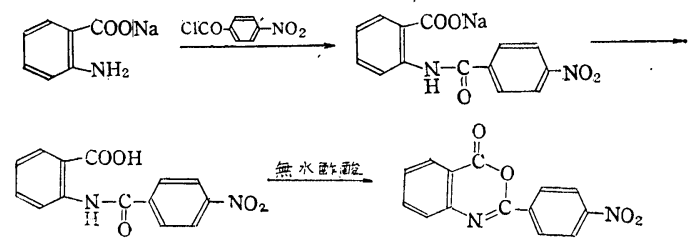<smiles>NC(=O)c1ccccc1NC(=O)c1ccc(-c2ccc3nc(-c4ccc([N+](=O)[O-])cc4)[nH]c(=O)c3c2)cc1</smiles><smiles></smiles><smiles>O=C(COc1ccccc1)Nc1ccc(-c2nc3ccccc3c(=O)[nH]2)cc1</smiles>

(13)

シアンアセトアニリド型のカップラーは, 通常の $p-$ フェニレンジアミン系発色現像薬で現像すると, 生成色 素の吸収が長波長側に延びて，マゼンタに近くなる。し かし，つぎのものは，4-アミノ-5-ピラン゙ロンなどの複 素環化合物を現像薬として現像すると, 長波長部の切れ のよい黄色を与える色素を生成する ${ }^{11)}$ 。

$$
\mathrm{CNCH}_{2} \mathrm{CONH}-2 \int_{\mathrm{SO}_{3} \mathrm{HI}}^{-\mathrm{N}^{-}}-\mathrm{CH}_{16}
$$

特異なものとして，活性なイミノ基を有するものがあ る。インダゾロンなどは，後記のように，カルボニル基 の 0 -位にある窒素原子に, 発色現像 薬の酸化生成物が カップリングして，色素を生成するのが通例であるが， この窒素原子（2-位）に置換基のあるものは，特異な反 応を示す。すなわち，インダゾロン環が開いて，1-位の 窒素原子にカップリングが起り，アゾ色素ができる。2-
位にカルボニル基があるものは，オレンジに発色し，さ らに 5-位にスルホンアミド基があるものは，マゼンタ に発色する。4-位に置換基があるものは，つぎのように 黄色を与え，しかも，アゾ色素となるので，酸や光に対 してきわめて安定である。また，カップラーの発色力む 強い(2)。
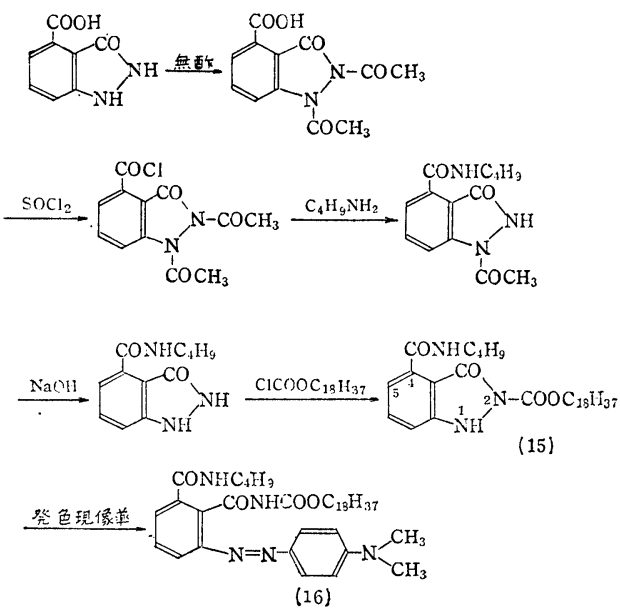

2. マゼンタを与えるカップラー マゼンタ色素は 可視域の $550 \mathrm{~m} \mu$ 付近に吸収極大をもち, $500 \mathrm{~m} \mu$ 以下 および $600 \mathrm{~m} \mu$ 以上を，完全に透過するものであること が望ましい。使用されているものは，ほとんど 1-フェ ニル-5-ピラゾロン誘導体である。置換基 $\mathrm{X}, \mathrm{R}, \mathrm{R}^{\prime}$ の変 化による生成色素の第二吸収極大 の減少, 発色速度, 発色濃度, 吸 収曲線の長波長部の切れなどが研<smiles>[R]C1=NN(c2ccc([R])cc2)C(=O)C1</smiles>
究の重要な分野となっている。

特に, 強い主吸収 ( $\mathrm{x}$ 帯) と, それよりも短波長側に 現われる弱い第二吸収 ( $\mathrm{y}$ 帯) との関係については, 多 くの物理有機化学的な研究がなされている ${ }^{13)}$ 。

i. 置換基 $\mathbf{X}, \mathbf{R}$ の工夫 これらの置換基は, カップ ラ一の溶解性, 発色速度, 生成色素の吸収曲線の長波長 部の切れなどに，主な影響を与える因子であって，つぎ のような研究がある。

塩素原子以外に, 新しくメチル基あるいはメトキシル 基などの陽性基を，ピラゾロン核の 1-位のフェニル基 に導入したのが特徵である ${ }^{14)}$ 。のカップラーは，カッ プラー溶剤によくとけ，吸収極大が少し短波長側によっ た，よい吸収特性をもった色素を生成し，熱や光に安定 で黄変しにくい。

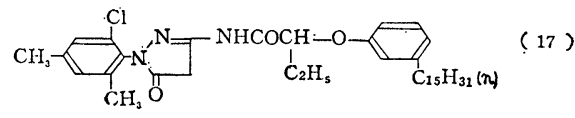


また，特殊なものとして，フェニル基の $o$-位にモノ 置換アミノ基を有するものが, Agfa 社から発表されて いる。このカップラーは, 青色部の不用な吸収が極めて 少なく, 安定性のよ色素を与える ${ }^{15}$ 。さらに, このア ミノ基と，ピラジロン核の 5-位のカルボニル基とが脱 水開環して, ピラゾロ $(1,5-\mathrm{a})$ ベンゾイミダゾールが得 られる。これまた，不用な青色吸収の少ない，耐酸性， 耐光性のよいマゼン夕色素を与えるが，やや黄変する ${ }^{16}$, 17)。

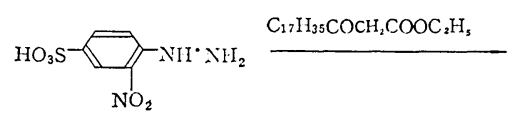

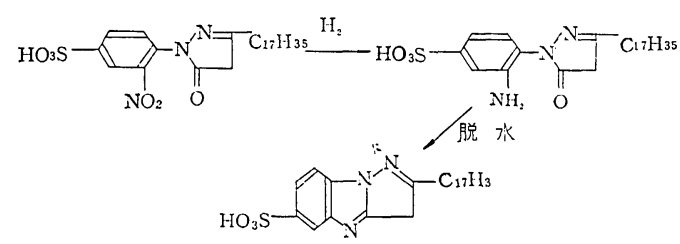

(19)

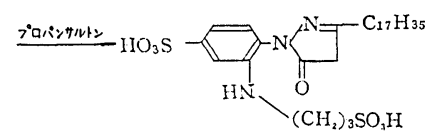

(18)

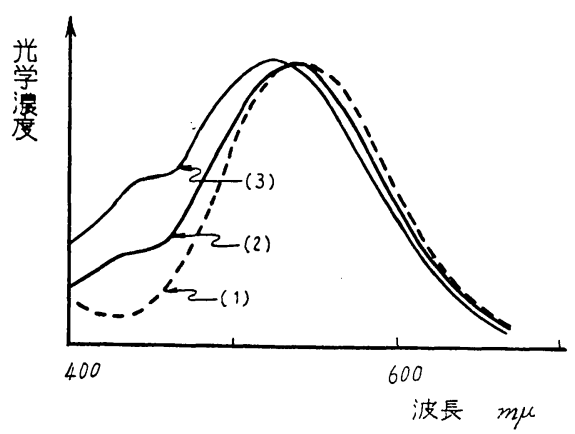

図 1

(1) ピラゾロヘンゾイミタゾール

(2) 1 フーニルー3-アャトアミル・゙ラ、からの色菜

(3) 1-フェニルー3ーメチルピラゾロン

ii. 置換基 $\mathbf{R}^{\prime}$ のエ夫 ピラゾロン核の 3-位の置 換 基 $\mathrm{R}^{\prime}$ が，アミノ誘導体である場合には，アルキル誘導 体にくらべて，一般に，生成色素の第二吸収が減少する ので，青色部の不用な吸収が少なくなる利点がある。

そこで， $\mathrm{R}^{\prime}$ をアミノ誘導体とするために，アシルア ミノ誘導体を使用するのが一般的であるが，中には特殊 なものとして，つぎのような㯰換基を有するものがあ る。
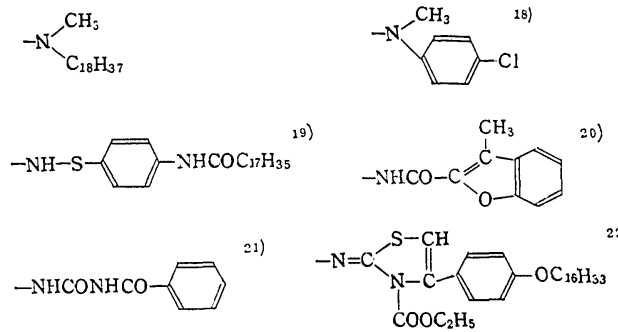

iii. 1ーフェニルー3-アニリノー5-ピラゾロン誘導体

これは前記と同じように，3-位の置換基 $\mathrm{R}^{\prime}$ についての 工夫である。この型のカップラーは，3-位がベンン゙イル アミノ誘導体のものにくらべて, 第二吸收がやや増大す る。しかし,ピラゾロン核の 3-位炭素の電子密度が増す ので，この影響を受けてカップラーの発色速度が，約 80 \%も速くなり, 発色濃度も約 $20 \%$ 高くなる ${ }^{23)}$ 。さらに, 生成色素の堅口ウ性がよく, 特に熱に強いなどの, 長所 をもったカップラーである。

この型のカップラーの合成法としては，つぎの 5 通り がある。

（1）脱アンモニア法年）一般的で，かつ最も古い方法 である。3-アミノ-5-ピラゾロン誘導体とアミノ化合物 とを, 無溶媒または氷酢酸, メチルセロソルブ, エチル セロソルブ，ピリシシンなどと共に，長時間加熱すると， アンモニアガスを発生して反応が進み, 目的物が得られ る。この方法は，アミノ化合物が，液体アミンである場 合には，特に有用である。

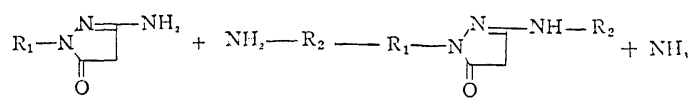

（2）活性ハロゲンまたは-SH 基を使 用する方法 ${ }^{25}$ 複素環化合物を縮合させるに有用な方法である。すなわ ち，活性なハロゲンを有するか，または環窒素の $\propto$-あ るいは, $r$-位に-SH 基を有する複素環化合物を, 水酢 酸またはピリジン中で, 3-アミノ-5-ピラゾロン誘導体 と反応させる。

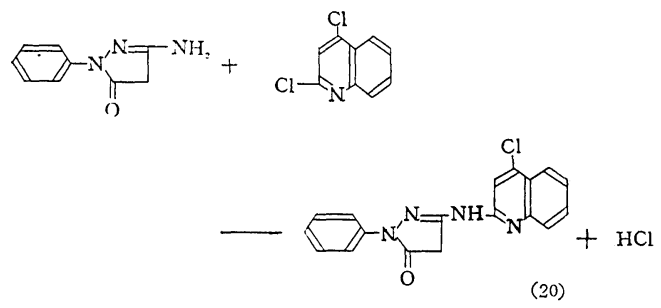

（3）アリールアミドランンンを使用する方法 ${ }^{26)}$ マロン 酸エステルーw-アリールアミドラゾンと，アミノ化合物 
とを，無溶媒またはピリジン，o-ジクロルベンゼン，ジ メチルホルムアミドなどと共に，加熱する。前記の脱ア ンモニア法よりも，収率がよい。

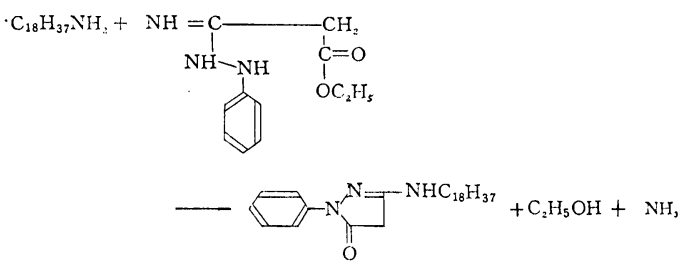

(21)

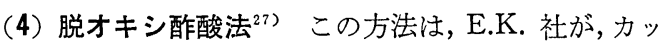
プラー（22）を発色現像に使用したところ，すべて (23) に変化することを発見した結果によるものである。これ は, フェノキシ基に置換している電子吸引性の強い二 ト口基の影響で，オキシ䣷酸が離脱し易くなるものと考 えられる。カップラー (22) を, カセイソーダを溶解し た含水アルコールにとかし, 室温でかきまぜると, ほと んど定量的にオキシ酢酸のナトリウム塩が析出してく る。このように, 複雑な分子中から, オキシ酶酸が極め て容易に離脱することは, 興味深く, 他の合成反応にも 利用し得るであろう。また，アニリノ基の-NH-に対し て，o-位に置換基を有するものも，この方法で合成で き, 生成色素は, 長波長部の切れのよい吸収を示す ${ }^{28)}$ 。<smiles></smiles><smiles>COC(=O)N1CC(=O)N(c2c(Cl)cc(Cl)cc2Cl)N1C(=O)OCC(C)O</smiles>

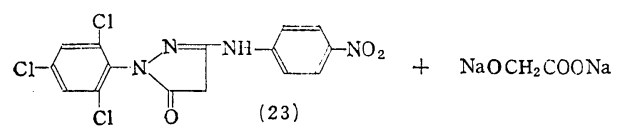

(5) $\boldsymbol{\beta}$-アリールアゾ- $\boldsymbol{\beta}$-メチルチオプロピオン酸エス テルを使用する方法 ${ }^{29)}$ 3-アミノ-5-ピラゾロン類を合 成するには，シアン酶酸エステル，または $\beta$-イミノー $\beta$ エトキシプロピオン酸エステルを使用する。この合成法 は，これらの代りに， $\beta$-アリールアゾー $\beta$-メチルチオプ ロピオネートを使用して，一気に目的物を得る方法であ る。 $\beta$-アリールアゾ基の変化によって, 種々の $3-ア=$ リノー5-ピラゾロンを合成し得る利点がある。

$$
\mathrm{Ar}-\mathrm{NH}-\mathrm{NH}_{2}+\underset{\mathrm{H}_{3} \mathrm{CS}^{\prime}}{\mathrm{A}} \mathrm{C}-\mathrm{CH}_{2} \mathrm{CO}_{2} \mathrm{CH}_{3} \longrightarrow
$$

$$
\begin{aligned}
& \mathrm{Ar}-\mathrm{NH}^{-\mathrm{N}=} \underset{\mathrm{CH}_{2}-\mathrm{CO}_{2} \mathrm{CH}_{3}}{\mathrm{C}-\mathrm{NHAr}}+\mathrm{CH}_{3} \mathrm{SH} \\
& \stackrel{\mathrm{t}=\mathrm{zh}}{\mathrm{zh}}-\mathrm{Ar}-\mathrm{N}_{\mathrm{O}}^{\mathrm{N}=} \mathrm{NHAr}^{\prime}+\mathrm{CH}_{3} \mathrm{OH}
\end{aligned}
$$

iv. その他 黄色カップラーとシアンカップラーに 使用する化合物の構造は，ほとんど限定されており，余 り変ったものはない。しかし，マゼンタ色素の分光吸収 領域は，両色素の中間にあるためか，この領域に吸収を もつ色素を与える化合物は沢山あるので，5-ピラン゙ロン 誘遒体以外の化合物で，実用性をもったものが多くあ $3^{30}$ 。

中でも, シアン䣷酸誘導体は前記のように, 黄色カップ ラーのみならず，マゼンタカップラーとしても使用可能 である。この系統のものとしてつぎのようなものがある。 いずれも, 生成色素の保存性のよいのが特徴である ${ }^{31}$ 。

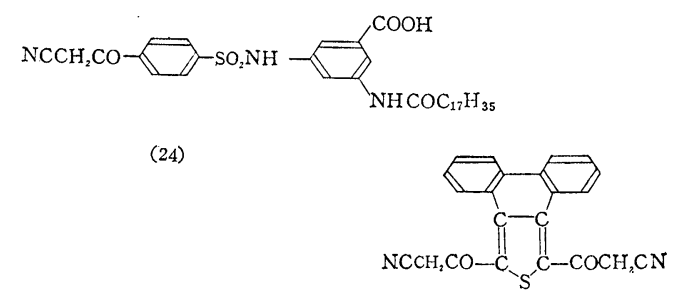

(25)

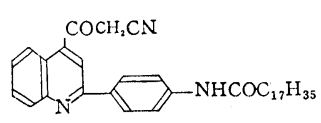

(26)

つぎに実用性の大きい化合物に,インダゾロン誘導体 がある。これは，活性なイミノ基を有するむのである が, 置換基の種類, 使用する発色現像薬の種類などによ って，発色が不十分となることがある。また，生成色素 の吸収が巾広くなり，黄色色素を副生することもある。 発色はつぎのようにして起る ${ }^{32}$ 。
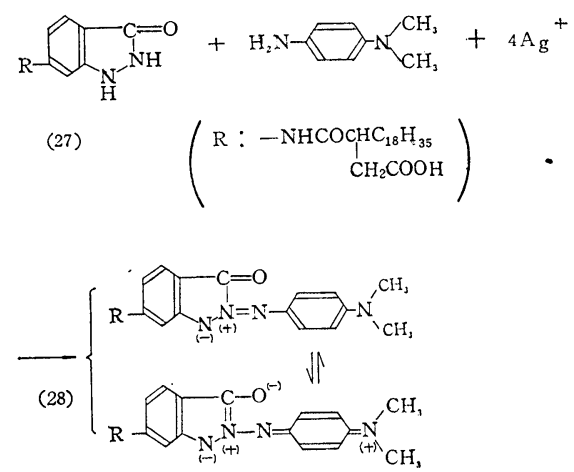
前記のピラゾロ $(1,5-a)$ ベンゾイミダゾールの同族と して，オルト縮合ピラゾロ化合物 ${ }^{17}$ である，ピラゾロ $(5,1-b)$ キナゾロン 33) (30) および，ピラゾロ $(3,4-b)$ キノリン誘導体 (32) がある。しかし，いずれも実用性 の点では，ピラゾロ $(1,5-\mathrm{a})$ ベンゾイミダゾール系にく らべて劣る。

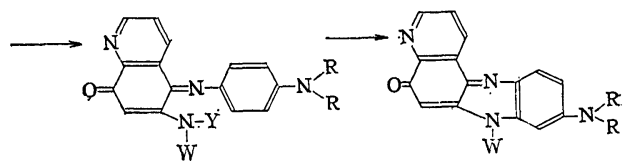

3. シアンを与えるカップラーシアン色素は可視 域の $650 \mathrm{~m} \mu$ 付近に吸収極大

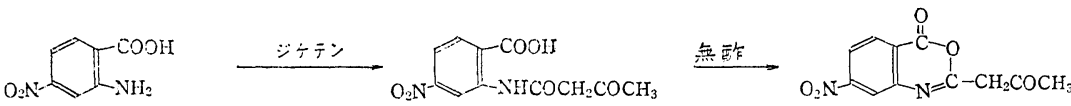
$\mid \mathrm{MH}_{2} \mathrm{NH}_{2}$ $\mathrm{O}_{\mathrm{N}}^{\mathrm{CONHNH}_{2}}$

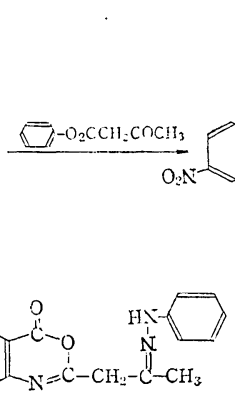

(29) をもち, $600 \mathrm{~m} \mu$ 以下を完全 に透過するものであることが. 望ましい。実用されているも のは,すべて,フェノール性水 酸基を有する化合物に限られ ている。すなわち,フェノール および, ナフトールの誘導体 であって, 㯰換基の種類と位 置の変化による, 発色速度, 発

また,3・アミノ·5・ピラゾロンと,1,3-ジカルボニル化合 物との縮合によって得られる 2 -オキシピラジロ $(1,5-a)$ ピリミジン類 (33) からは, 青ないし青紫色の発色が見 られるが，キノンイミン色素としては単離できない(34)。<smiles>COCCOC</smiles>

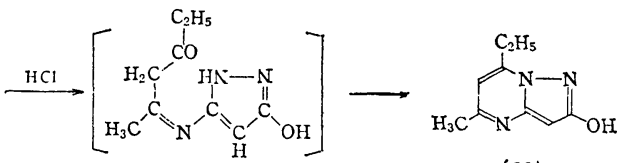

(33)

また，キノンイミン色素を生成して，マゼンタを与え るカップラーに，8-オキシ-6-N-置換キノリンがある。 これはさらに, 酸化されてアジン色素となる。これに使 用するカップラー, および, 色素の生成機構をつぎに示 す35。

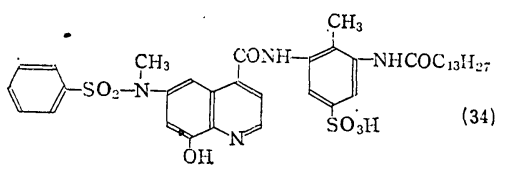

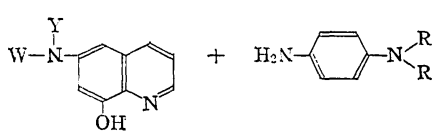
色濃度, 生成色素の吸収極大 の位置, 吸収曲線の短波長部. の切れ, 色素の堅ロウ性など が, 研究の焦点となっている。

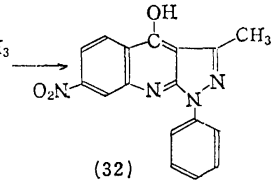

古い特許には，4,6-ジケトテトラヒドロピリミジン誘 導体 (35) や6-オキシー $\alpha$-ピリドン ${ }^{37}$ 誘導体 (36).など の, 複素環化合物を使用する例があるが, 最近では, この種のものは，あまり発表されていない。<smiles>CC1CCC(C2CCCCC2)=N1</smiles>

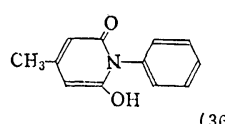

(36)

i. 置換基のエ夫 フェノールあるいは，ナフトール の水素基に対して，o-位に複素環化合物を導入すると， 一般には，生成色素の吸収極大が長波長側に移動する。 ところが，つぎのカップラーから得られた色素は，吸収 極大が移動せず，また堅ロウ性がよいという ${ }^{38 \% 。 ~}$

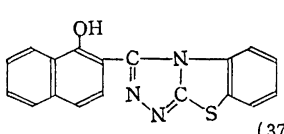

(37)<smiles>Oc1c(-c2nnc3ccc4ccccc4n23)ccc2ccccc12</smiles>

39)<smiles>CCOC(=O)OC1CCc2ccccc2C1O</smiles><smiles>CC1=CC2=NC1(C1CCCC1)N=C2c1ccc2ccccc2c1</smiles>
$2 \mathrm{H}_{2} \mathrm{O}$ 

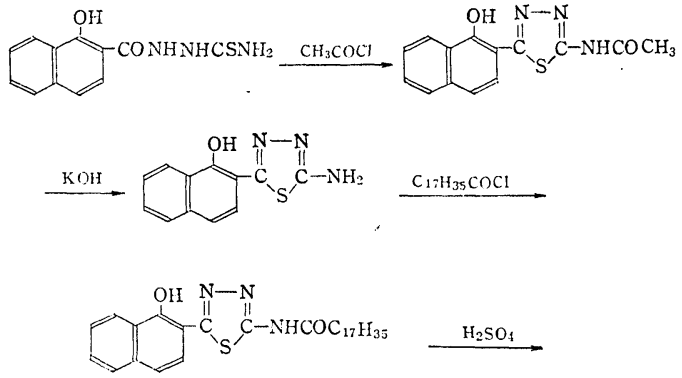<smiles>CCOC(=O)Nc1nnc(-c2cc([N+](=O)[O-])c3ccccc3c2O)s1</smiles>

緑色部の不用な吸収をできるだけ少なくし，堅口ウ性 のよい色素を得るために, フェノールの水酸基に対し て，2-または3-位に尿素結合を導入したもの ${ }^{41}$ ，あるい は，アルキルスルホン基を有する 1-オキシ-2-ナフトア ニリド42)などがある。

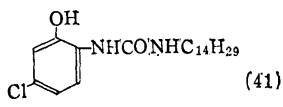

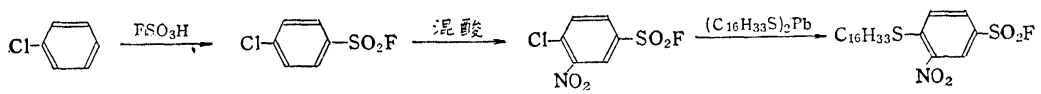

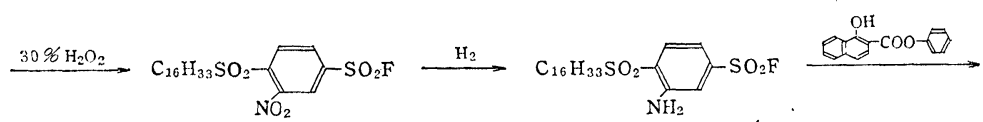

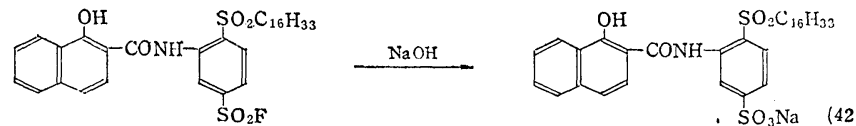

くらべて, 約 $50 \mathrm{~m} \mu$ も短波長側に吸収極大が移る。こ れは，アミドの水素をアルキル基などで㯰換すると， （47）のような水素結合がもはや起らないので，大きく 浅色移動するためである ${ }^{44}$ 。

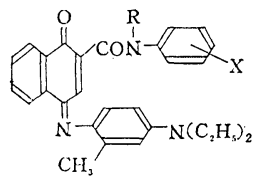

R $\mathrm{X} \quad \lambda_{\mathrm{m \times a}}($ メタノール)

H $712 \mathrm{~m} \mu$

(46) $\mathrm{CH}_{3} \mathrm{H} \quad 662 \mathrm{~m} \mu$

(44)

ところが，アニリド核の置換基Xの位置が変っても， 吸収極大の移動は, Xの種類に関係なく,たかだか $7 \mathrm{~m} /$ 程度である。このように, アニリド核の置換基Xの位置

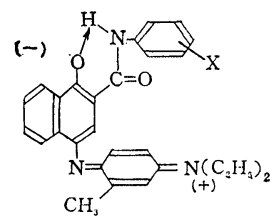

また，同じような特性をもったものとして，5, 6, 7,8テトラヒドロ-1-オキシ-2-ナフトアニリド誘導体があ $ろ^{433}$ 。<smiles>CN(C)c1ccccc1NC(=O)c1ccc2c(c1O)CCCC2</smiles>

ii. 色と構造 置換基の導入された位置, 置換基の種 類などによって，生成する色素の吸収，したがって，色 がいちじるしく変ることはよく知られた事実である。色 素の色と化学構造との関係については, 多くの研究があ る。

たとえば，1-オキシ-2-ナフトアニリド型カップラー から得られる色素 (44) に掠いて，アミドの水素をアル キル基で置換すると（46)，置換していないもの（45）に
の違いは，色に余り大きな影 響を与えないものと考えられ ていたが, 最近, 珍らしい事 実が発表された。すなわち， 1ーオキシー2-(アセトアミド - $\beta$ ーフェニルチル)-ナフト アミドから得られる色素 ${ }^{45}$ に おいて，アセトアミド基が 0 位にあるもの（53）から得ら れる色素は, $p$-位にあるむの (48)にくらべて, 吸収極大が

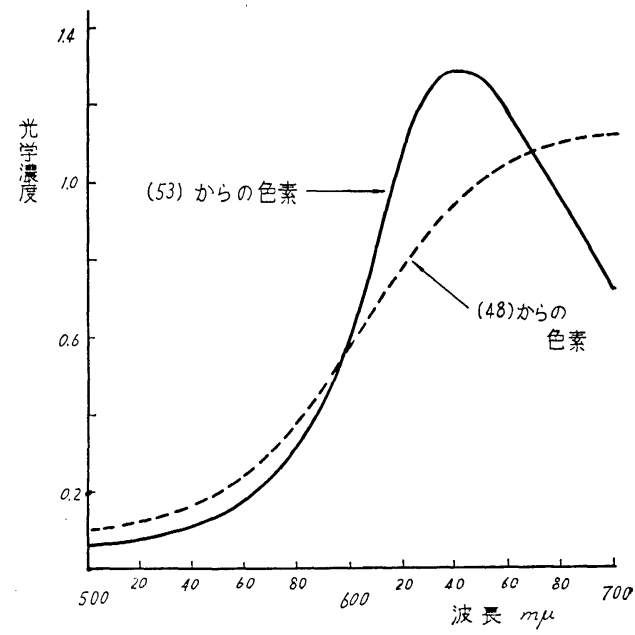

図 2 写真フィルム中の吸収 
約 $60 \mathrm{~m} \mu$ も短波長側に大きく移動することである。こ の吸収極大の移動は, 写真フィルム中でのことなので, ゼラチンなどの基質の影響があるとはいえ，余りにも大 きい。また，図 2 に示すように，吸収の币も狭く，理想 的な吸収特性をもった色素である，この差違は，生成す る色素結晶が，p-体は無定形であるのにくらべて，o-体 は微細結晶形をとるためである。

このように，o-体は特異な吸収を示す色素だけに，不 純物の影響を受けやすいので，カップラーの合成法も複 雑となり, 純粋な 0 -ニトロトルエンを出発原料とする, (D)の経路をとる。 $p$-体の合成経路 (A) と同じように, 芳香族アミンと, 脂肪族アミンとの反応性の差を利用し で6)，まず，1-オキシ-2-ナフトエ酸フェニルエステル と, 脂肪族アミンとを優先的に反応させたのち, 芳香族 アミンをアセチル化して，目的物を得るところの，(C) の経路をとることはできない。ノ ð4. 可溶化基, 耐拡散基のエ夫 カップラーをゼラ チン乳剤中に分散し，フィルムベースに塗布・乾燥 し て, カラー写真感光材料を得るのに使用するところの, いわゆる，内型カップラーは，カップラーが添加された 乳阂層から，他の層へ拡散渗出するのを防ぐ必要がある。 そのため, カップラー分子中に, 炭素数が 14 以上の脂 肪鎖，あるいはアリール基を導入する。これを，耐拡散 基 (ballast group) と言う。さらに，カップラーのアル カリあるいはカップラー溶剤への溶解度をよくするため にも，同時に，いろいろな工夫が必要であり，多くの研 究がなされている。

i. 水溶性カップラー カップラーを，水またはアル カリ溶液にとかしてから，ゼラチン乳剤中に分散する型 では，可溶化基として，-OH, $-\mathrm{COOH},-\mathrm{SO}_{3} \mathrm{H}$ 基などを 導入する必要がある。これらの導入法としては, つぎの 3 通りがある。

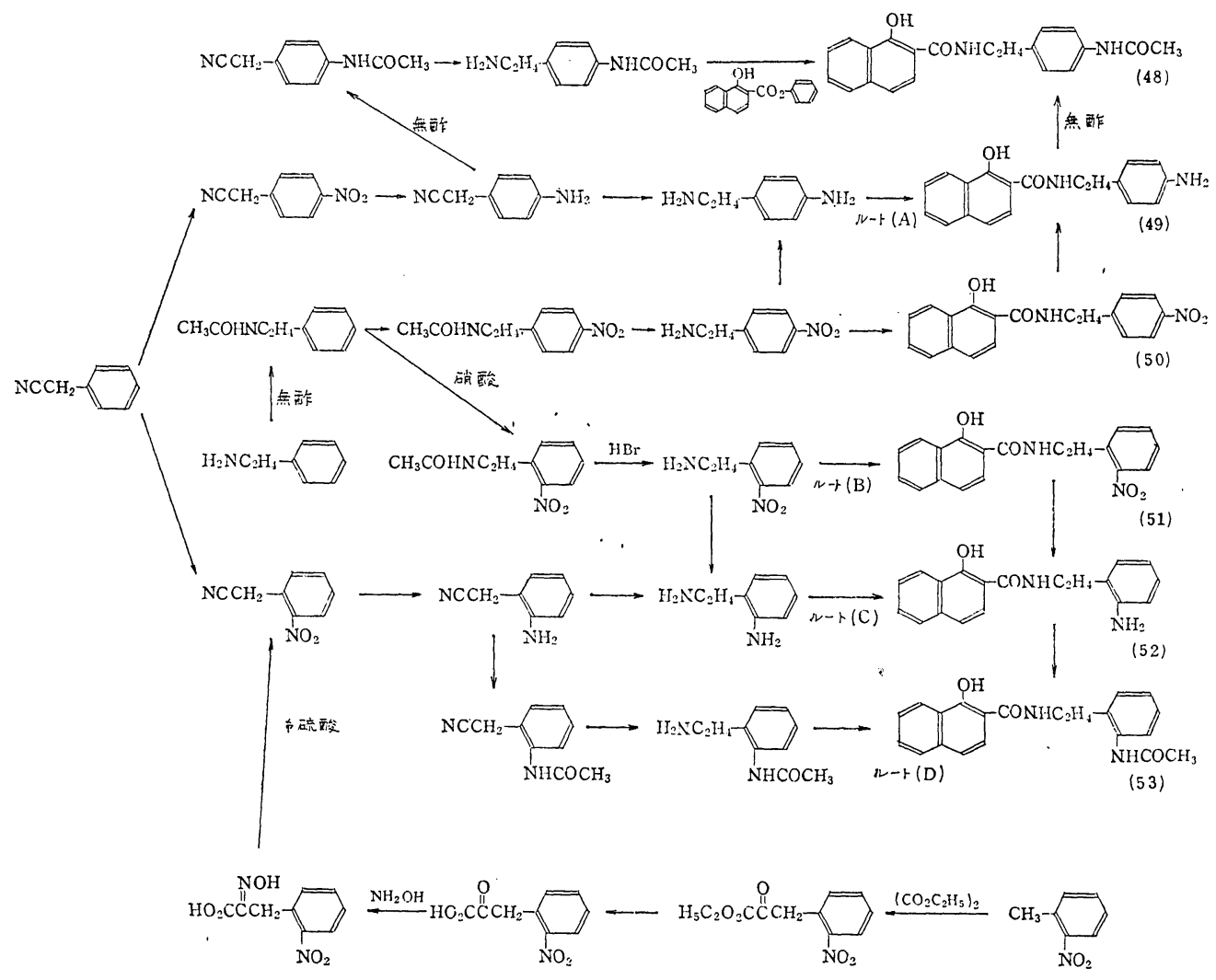

ん(1) 酸塩化物または酸無水物を使用する方法、これら の可溶化基を有し，かつ，耐拡散基ともなり得る化合物 を，酸塩化物または酸無水物に導き，カップラー母核中 のアミノ基と反态させる方法である。これは，もっとも 一般的で，また実用性の高い方法であり，カップラー母
核と耐搪散基(可溶化基)とを別々に合成し得るなどの， 便利さがある。酸塩化物としては，カルボニルクロリド を，酸無水物としては，マレイン酸またはグルタミン酸 を使用するのが，一般的である。しかし，酸無水物の場 合には，開環する位置の違いによって，2 種の異性体が 


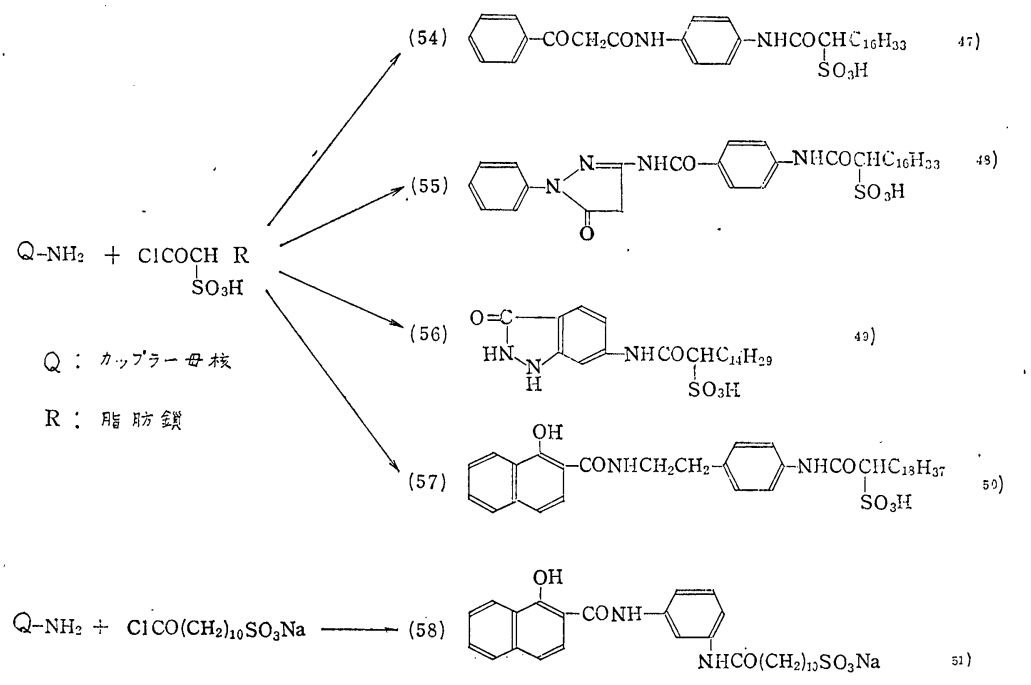

生成する。すなわち, マレイン酸の場合には， $\alpha$-と $\beta$ 異性体, グルタミン酸の場合には, $\alpha$-と $r$-異性体の混 合物となり，どちらの含量の方が多いかは明らかでな

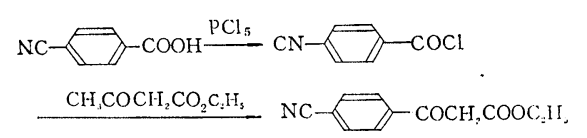
い。酸無水物の誘導体として, $\mathrm{S}$ または $\mathrm{SO}_{2}$ を含有す るもの ${ }^{52)}$, あるいは, -NHCO-を有するもの ${ }^{53) な と ゙ か ゙ ~}$ ある。

$$
\mathrm{Q}-\mathrm{NiH}_{2}+\mathrm{O}_{\mathrm{CO}-\mathrm{CH}_{2}}^{\prime \mathrm{CO}-\mathrm{CH}-\mathrm{S}-\mathrm{R}}-
$$

(ll

(59)

(60)

$$
\mathrm{Q}-\mathrm{NH}_{2}+\overbrace{\mathrm{CO}-\mathrm{CH}_{3}}^{\mathrm{CO}-\mathrm{CH}-\mathrm{NHCOR}}
$$

$$
\mathrm{Q} \rightarrow \mathrm{NH}_{2}+\mathrm{O}_{\mathrm{O}-\mathrm{CH}}^{\mathrm{OO}-\mathrm{CH}-\mathrm{NHCOR}} \underset{1}{\mathrm{C} \mathrm{H}_{2}}
$$

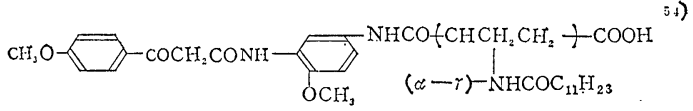

(2) カップラー母核に直接導入する方法 前記の可溶 化基を, カップラー母核に直接導入することはむずかし く, 特に- $\mathrm{SO}_{3} \mathrm{H}$ 基の場合には困難であり; いろいろの 工夫がなされている。- $\mathrm{COOH}$ 基の場合には， $-\mathrm{CN}$ 基を 加水分解する方法がある ${ }^{55)}$ 。
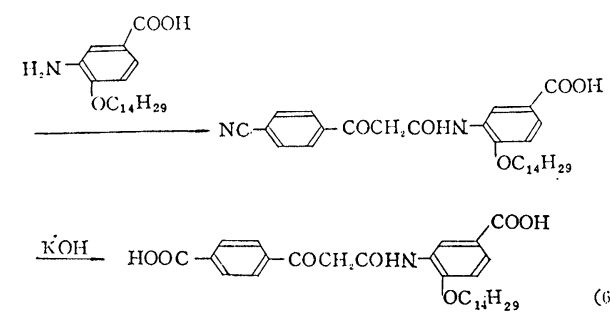

$\mathrm{SO}_{3} \mathrm{H}$-基の場合には， $-\mathrm{SO}_{2} \mathrm{~F}$ 基を加水分解する方法 ${ }^{56)}$ ，濃硫酸，または，クロルスルホン酸でスルホン化す る方法 ${ }^{57}$ などがある。また，スルホン酸化合物を，トリ エチルアミン塩にしてから反応させる方法 ${ }^{58}$ について， 富士写真社が発表している ${ }^{59)}$ 。
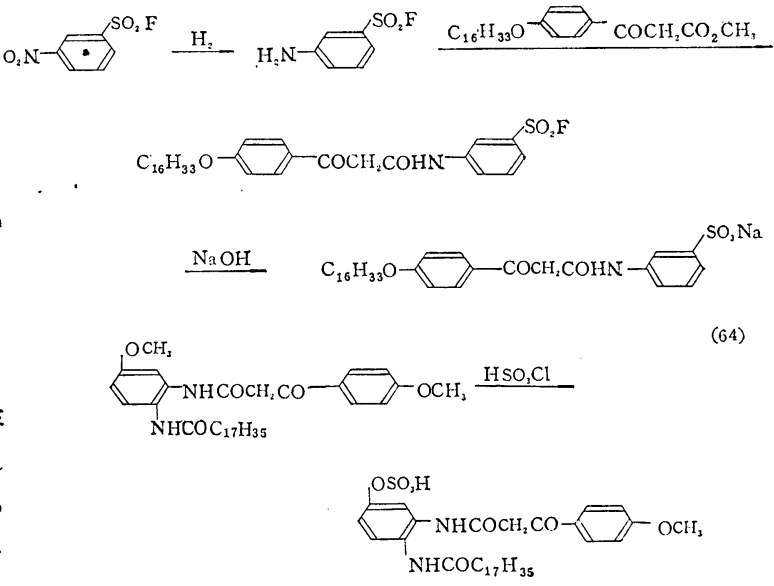

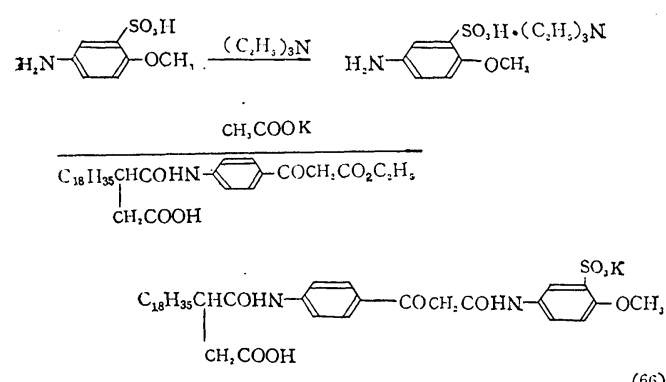

(60)

また，-OH 基の導入については，つぎの例がある ${ }^{60)}$ 。

$\underset{S O_{1} \mathrm{II}}{-\mathrm{NHNH}_{2}} \stackrel{\left(\mathrm{HO}_{2} \mathrm{C}_{17} \mathrm{H}_{3} \mathrm{COCH}_{3} \mathrm{CO}_{2} \mathrm{C}_{3} \mathrm{I}_{2}\right.}{2}$

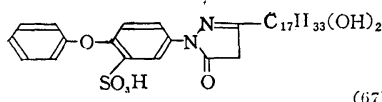

(6i)

（3）その他 フタルイミド誘導体を耐拡散基としたも のは，そのま〉カップラー溶剤にとかして使用し得る し，アルカリにとかせば，環が開いて遊離の- $\mathrm{COOH}$ 基 ができるので，アルカリ可溶性にもなる ${ }^{61) 。 ~}$

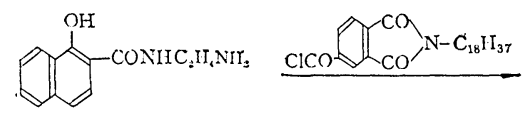

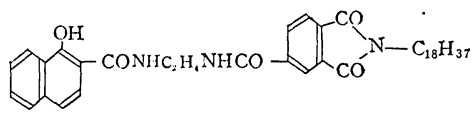

(68)

ii. 油溶性カップラー カップラーを，有機溶剤ある 、は可塑剤などにとかしてから，ゼラチン乳剤中に分散 する型では, カップラー溶剤一の溶解度をよくし，また 分散したカップラーが，乳剂中で析出しないようにする ために，耐搪散基に苦心がはらわれている。それらの中 沈，つぎのようなものがある。

（1）エーテル結合を有するもの 耐拡散基中にエーテ

ル結合を導入して，分子内部回転の自由度をまし，エン トロピーの増大による, 溶解度の上昇をねらったもので ある。

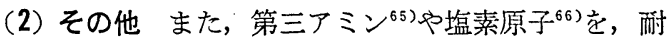
拡散基中に有するものがある。

$$
\begin{aligned}
& \mathrm{C}_{4} \mathrm{H}_{9} \mathrm{NHI}_{2} \stackrel{\mathrm{CH}_{2} \mathrm{CHCO}_{2} \mathrm{CH}_{3}}{\longrightarrow} \mathrm{C}_{4} \mathrm{H}_{9} \mathrm{NHC}_{2} \mathrm{H}_{4} \mathrm{COOCH}_{3} \stackrel{\mathrm{C}_{13} \mathrm{H}_{27} \mathrm{COCl}}{\longrightarrow}
\end{aligned}
$$

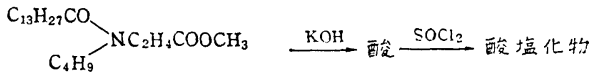

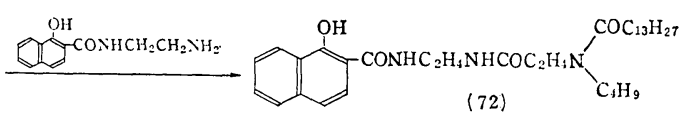

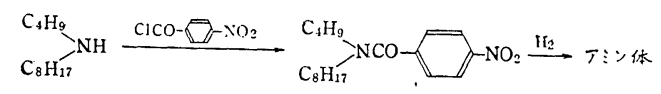

D $-\mathrm{COCH}_{2} \mathrm{COOC}_{2} \mathrm{H}_{5}$

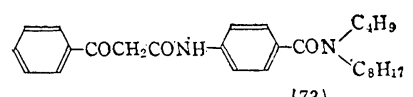
(73)

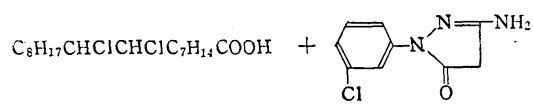

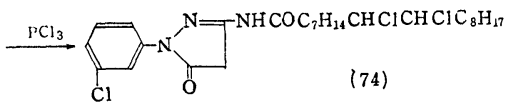

\section{5. カップリング位置に置換基を有するカップラー} 発色現像薬の酸化生成物がカップリングするところの， 炭素原子上の水素原子が置換されたカップラーは，その 置換基の種類，置換された水素原子の数によって，いろ いろの性質と用途をもっている。すなわち，発色効率の よいカップラー, カラードカップラー, 無呈色カップラ 一，スプリタブルカップラーなどが得られる。

i. 発色効率のよいカップラー カップラーと発色現 像薬の酸化生成物とがカップリングして，色素となるた

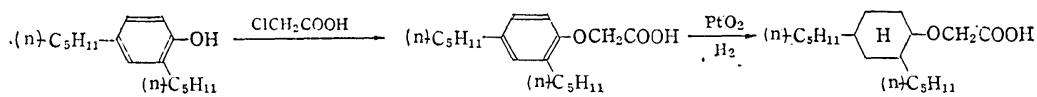

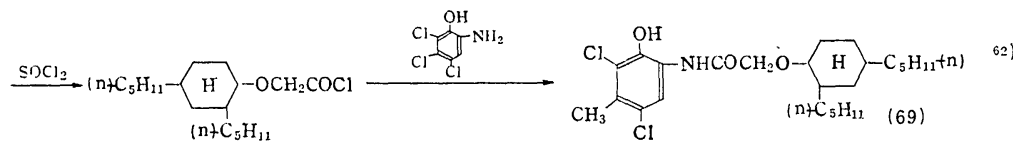

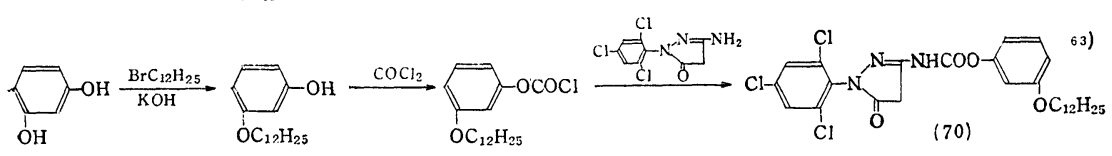

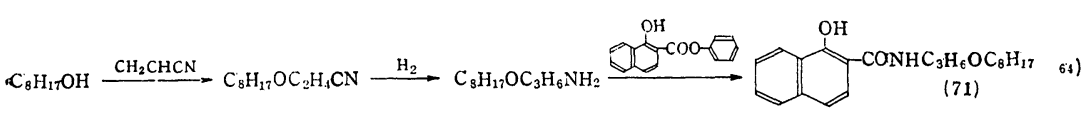
めには, $4 \mathrm{Ag}^{+}$が必要で ある。ところがこのカッ プラーは $2 \mathrm{Ag}^{+}$で色素 $1 \mathrm{~mol}$ を生成するので, 発色北必要なハロゲン化 銀の量が半分でよい。し たがって, カラー感光材 料の乳剤コストが安くな り，また，乳剤膜層を薄 くできるなどの利点があ る。 
置換基は, 発色現像薬の酸化生成物と容易に交換反応 乙, 離脱したのちも，乳剤に悪影響を与えないものであ ることが望ましい。これに適するものには， $-\mathrm{SO}_{3} \mathrm{H}$ 基 (40) 八ロゲン原子 (59), (60), (69) などがあるが67),

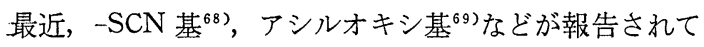
いる。
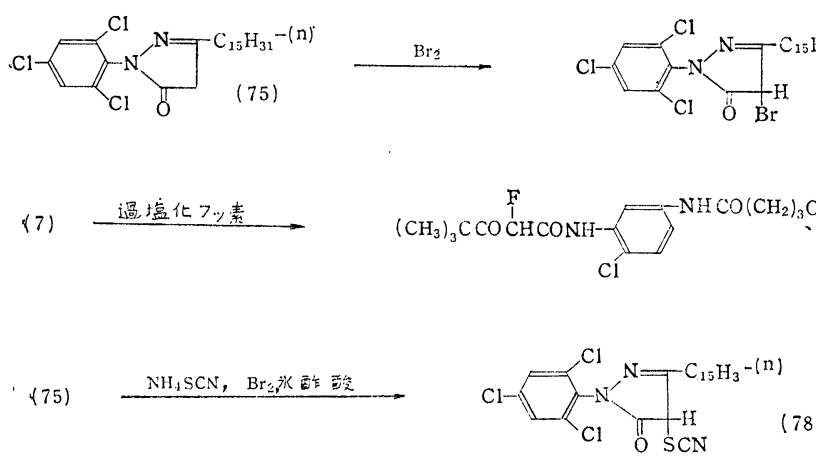

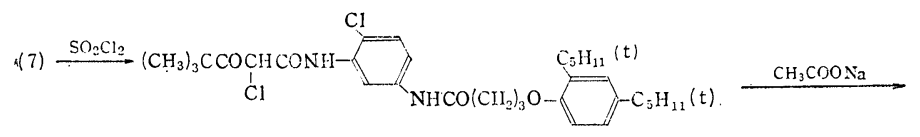

(79)

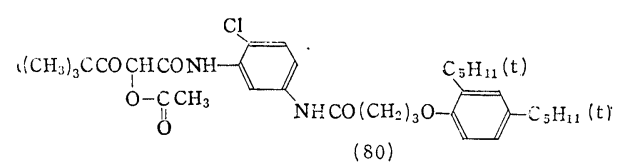

(80)

ii. カラードカップラー マゼンタ色素とシアン色 素とは，ともに，理想的な分光吸収特性をもったものが ほとんどないので，これらの不用部分の吸収を補正する ために，アン゙色素であるカラードカップラーを使用す る。したがって，カラードカップラーは，色補正に適応 した分光吸収特性を示すと同時に，アゾ置換部は，発色 現像薬の酸化生成物と容 易に交換反応を起し，乙 かも, 離脱・分解生成物 が，乳剤に悪影響を与え ないものであることが必 要である。

使用されているもの は, 発色現像の前後とも に，有色の色素 (82) で ある70)。乙かし，中に は，黄ないし橙色の色素 で; 発色現像後, 無色化 合物となるも ${ }^{71)}$ (84), また，無色カップラーか ら, 発色現像後, マゼン タなどの色素となるもの 72)（86）および，無色な いし黄色の色素で, 発色 現像後, マゼンタ色素に かわるもの ${ }^{73)}$ (89) など がある。
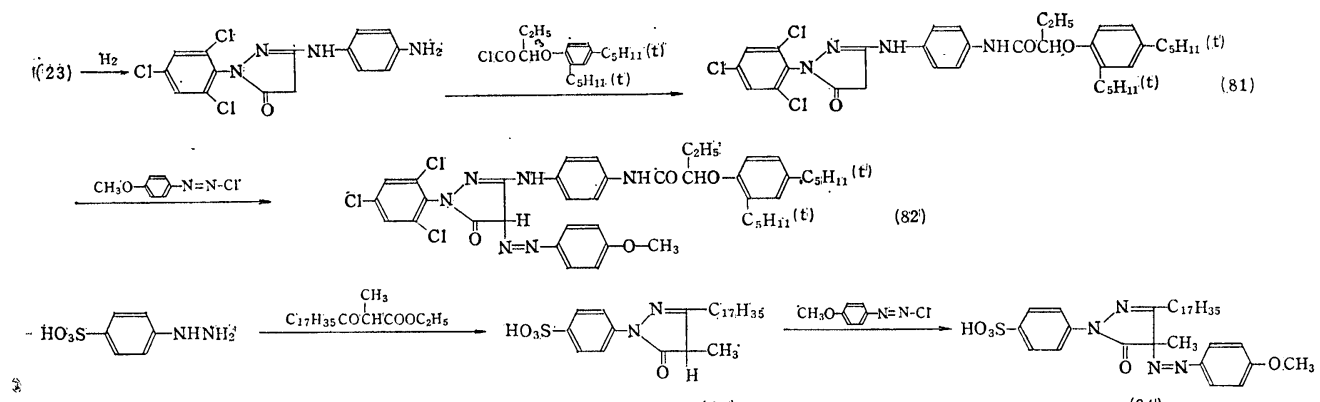

(83)

(84')

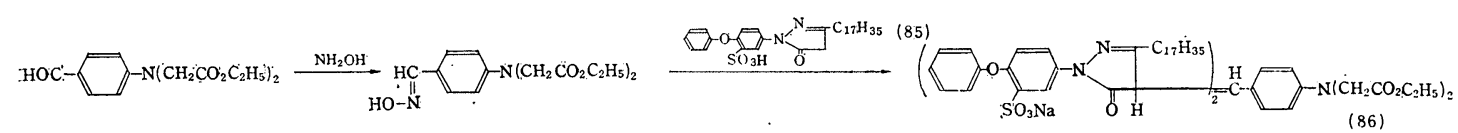
(86)

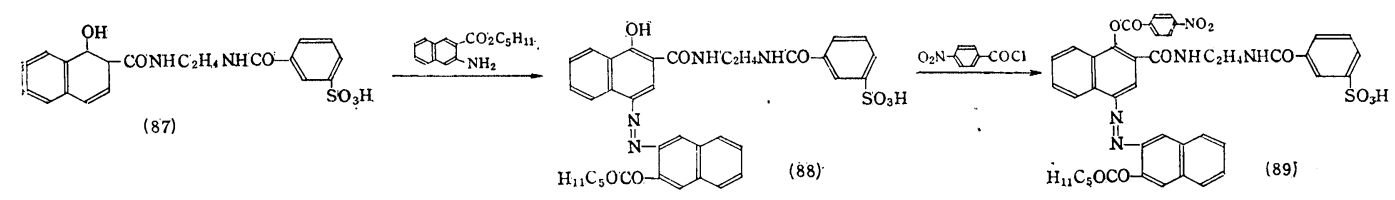


iii. 無呈色カップラー カップリング位置にある 置 換基を離脱することなく，発色現像薬の酸化生成物とカ ップリングして，無色化合物となるカップラー (83) で ある ${ }^{74)}$ 。発色現像薬の酸化生成物は, 自己カップリング して, 茶カッ色の色素 (90) となり，カラーフィルムの 色再現に悪影響を与える。よって，これをカップリング して，無害な無色化合物（91）にしてしまうわけである。
さらに，他の方法に使用する素材としては，色素漂白 法用染料, ゼラチン染色用の反応性染料 ${ }^{85)}$, 染 料現 像 薬， $3 \mathrm{M}$ 法用の染料・顔料などがある。

これらの素材についても，新しい発展が見られる。特 に，CIBA 社からは，多数の銀色素漂白法用染料が特許 として発表されており，今後の進展と実用化が期待され ている。
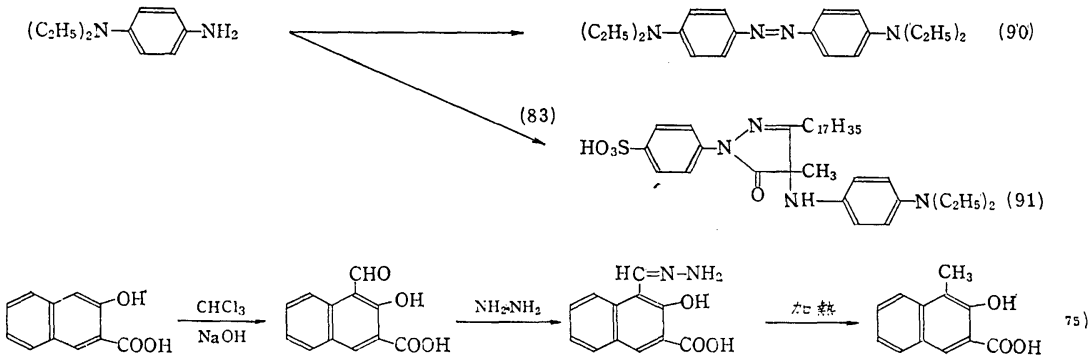

(92)

しかし，与えられた紙 面の都合で，総説の内容 を，発色現像法用カップ ラーにしぼったので，他 の有機素材については， 残念ながら割愛せざるを 得なかった。

カラー感光材料の発展 には，常に，新しい有機 合成化合物を要求してお り，これからも，有機素 材の役割は，ますます大 (93) きくなるであろう。この時に，この小文が，諸賢のカラ 一写真への興味を深める一助ともなれば，幸である。 (昭和 40 年 7 月 15 日受理) 像薬の酸化生成物とカップリングして，色素を生じると 同時に， Rの種類によっては，現像抑制剤77) 離脱し (95)，またケイ光化合物を離脱する ${ }^{78)}$ なと，広い応用面 をもったカップラーである。

1) Popular, Photography 3114 (1963); Brit. J. Phot. 176 (1963)

2) M.M.M. 日特公 昭 38-15,444

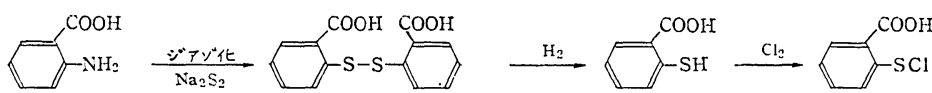

3) T.J. Kvcera, Perspective 4 No. 3133 (1962)

4) Belg. $P$ 616,867 (1962)

5) $D B P 1,124,356$ (1961)

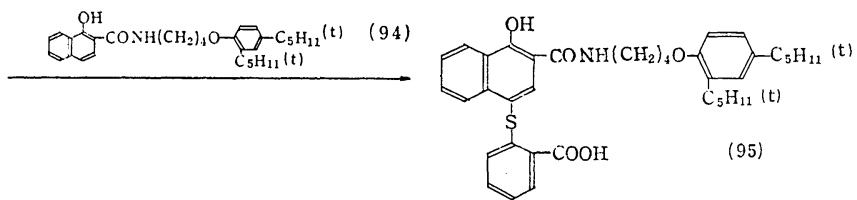

6) 永井, 松尾, 有合化 234 (1965)

7) E. Wahlberg, Ber. 442072 (1911)

8) VEB (Wolfen), $D B P$ $1,187,479$ (1964)

あとがき

カップラーが，分子中に有する反応性基で，反応性染 料のように，ゼラチンあるいは高分子化合物と結 合し て，耐拡散性となりうるカップラー(反忘性カップラー) について最近，発表された ${ }^{79)}$ 。

この他, 発色現像法カラ一写真には, 青色光を吸収す るフィルター染料 ${ }^{80)}$ ，色分離用染料，ハレーション防止 用染料, 増感色素, 污染防止剂 (酸化防止剂) ${ }^{81}$, 紫外線 吸収剂 ${ }^{82)}$ ，安定剂，発色現像薬 ${ }^{83) ， ま た ， カ ッ フ ゚ ラ ー と ~}$ ポリマーからなる高分子カップラー ${ }^{84)}$ ，などの，数多く の有機素材が使用されている。
9) Gevaert, $B P 873,125$ (1961)

10) Gevaert, $B P 856,158$ (1960)

11) General Aniline, USP 3, 034, 891 (1962)

12) I.C.I, $B P 875,470$ (1961)

13）小野, 谷崎, 田中, 写真学会誌 21115 (1958); W.F. Smith, J. Phys. Chem. 681501 (1964)

14) Eastman Kodak, USP 3,062 653 (1962)

15) $B P 892,886$ (1958)

16) BP 918, 128 (1959); Belg. P 643, 802 (1964)

17) K.H. Menzel, R. Pütter, G. Wolfrum, Angerv. Chem. 74839 (1962)

18）小西六, 日特公 昭 39-14439

19) Adox, $D B P$ 1, 103, 761 (1960)

20) Ilford, $B P$ 890, 305 (1960)

21) Gevaert, Belg. P 644, 330 (1964) 
22) Gevaert, Belg. P 643, 146 643, 149 (1964)

23）富士写真, 日特公 昭 40-6031

24) Eastman Kodak, USP 2, 311, 082 (1943)

25) Gevaert, USP 2, 619, 419 (1952)

26) General Aniline, $D B P$ 1, 101, 429 (1961)

27) Eastman Kodak, USP 2, 983, 608 (1961)

28) Ilford, $B P$ 956, 261 (1962)

29) Eastman Kodak, $D B P$ 1, 176, 478 (1964)

30) W. Pelz, Mitteilung aus Agfa Gesellschaft 3 126 (1961)

31) Ferrania, DBP 1, 187, 478 (1963); CIBA, Belg. $P$ 642,525 (1964); 日特公 昭 39-27, 565

32) Gevaert, USP 2, 964, 402 (1960); Agfa, Belg. $P$ 613, 328 (1961)

33) Agfa, $D B P$ 1, 111, 505 (1960)

34) W. Ried, K.P. Peuchert, Ann. 660104 (1962); Adox, $D B P$ 1, 150, 872 (1962)

35) General Aniline, $B P$ 837, 360 (1958)

36) Eastman Kodak, USP 2, 350, 812 (1944)

37) General Aniline, USP 2, 293,004 (1942)

38) Eastman Kodak, USP 2, 976, 146 (1961)

39) Ferrania, Fr. P 1, 323, 977 (1962)

40）富士写真, 日特公 昭 34-4085

41) Agfa, $D B P$ 1, 163, 144 (1962)

42) Gevaert, $D B P 1,109,522$ (1961)

43) Agfa, $D B P$ 1, 137, 311 (1961)

44) C. R. Barr, G.H. Brown, J.R. Thirtle, A. Weissberger, Phot. Sci. Eng. 5195 (1961)

45) Eastman Kodak, USP 3, 002, 836 (1961)

46) Eastman Kodak, USP 2, 589, 004 (1948)

47) 富士写真, 日特公 昭 $35-18,333$

48) General Aniline, BP 833, 596 (1956)

49) Agfa, Belg. P 613, 328 (1961)

50）富士写真, 日特公 昭 38-18, 145

51) General Aniline, Belg. P 590, 403 (1960)

52) I.C.I. $B P 858,482(1959)$

53) I.C.I., $D B P \quad 1,115,129$ (1961)

54) I.C.I, $B P$ 858, 564 (1959)
55) General Aniline, USP 3, 056, 674 (1962)

56) Gevaert, $B P$ 808, 276 (1956)

57) CIBA, Belg. P 636,700 (1963)

58） 富士写真, 日特公 昭 $36-21,711$

58）富士写真, 日特公 昭 40-6030

60) Agfa, Belg. $P$ 611, 885 (1960)

61) Ilford, $B P$ 944, 838 (1960)

62) Eastman Kodak, $B P$ 865, 492 (1961)

63) Perutz, $D B P$ 1, 176, 479 (1963)

64）富士写真，日特公 昭39-27, 563

65） 富士写真, 日特公 昭 39-2；837,2,839

65) Perutz, $D B P$ 1, 171, 742 (1963)

67) Eastman Kodak, USP 3,006,759 (1961); BP 944, 490 (1961)

68) Eastman Kodak, Fr. P 1, 287, 280 (1961)

69) Eastman Kodak, $D B P$ 1, 181, 057; 1, 187, 477 (1963)

70) Eastman Kodak, USP 2,983,608; 3, 005, 712 (1961); 3, 034, 892 (1962)

71) Agfa, $D B P$ 1, 150, 275 (1957)

72) I.C.I., USP 2, 998, 312 (1961), Ilford, Belg. $P$ 622, 365 (1962)

73) Eastman Kodak, USP 2, 860, 974 (1958)

74) Agfa, BP 861, 138 (1961)

75) Agfa, $D B P$ 1, 099, 350 (1959)

76) Ferrania, $F r . P 1,340,552$ (1962)

77) Eastman Kodak, Fr.P 1, 257, 887 (1960)

78) Eastman Kodak, BP 945, 542 (1960)

79）富士写真 Belg.P 656, 456 (1965)

80) Perutz, $D B P 1$ 1, 104, 335 (1961); ClBA, $B P$ 888, 527 (1962)

81) Eastman Kodak, $B P$ 891, 158 (1958)

82) Eastman Kodak, USP 2,739, 888 (1956)

83) Du Pont, USP 3, 047, 388 (1962); Agfa, BP 918, 129 (1959)

84) Du Pont, USP 3, 073, 699(1963); M.M.M. USP Re. 25, 586 (1964)

85） CIBA，日特公 昭 39-8369 